\title{
Identifying the Competence Components of the Construction Project Managers in the Palestinian Construction Industry
}

\author{
Abdelnaser Omran ${ }^{1 *}$ and Akram Subhe Hardam Suleiman ${ }^{2}$
}

\begin{abstract}
This study aimed at identifying competency components of project managers of small to medium-sized firms in the Palestinian construction industry and ranking them according to their degree of importance. A postal questionnaire survey was administered to 150 construction companies in Nablus, Tulkarm, and Jenin, which are located in the West Bank. A total of 109 questionnaires were returned, and the response rate was 73 percent. The respondents were project managers. The study identified four competence dimensions, namely, knowledge competence, functional competence, personal/behavior competence, and value/ethical competence. Each dimension is measured by several constituents. Knowledge dimension includes technical knowledge, management knowledge, general knowledge, communication knowledge, computer knowledge, financial knowledge, and legal knowledge constituents. Functional competence dimension includes seven constituents, namely, organizing project initiations, developing a project plan, managing human resource functions, managing project quality health safety and environment, managing design development and contract administration, tracking and controlling system, and administering project close out. Personal competence dimension has two constituents, namely, social-vocational and intraprofessional. Values/ethical competence dimension consists of two constituents, namely, personal values and professional values. Thus, personal competence is in the top ranking followed by functional competence, knowledge competence, and values competence. Finally, a mixture of knowledge, functional, personal, and values competences must be considered to produce a competent project manager in the Palestinian construction industry. This study recommends that the Palestinian Contractors Union and the Palestinian Engineers Association improve the competencies of their members by conducting continuous and up to date construction management training programs by targeting competencies included in this research..
\end{abstract}

\section{Keywords}

Competencies, Construction Industry, Components, Project Managers, Palestine

\footnotetext{
${ }^{1}$ School of Economics, Finance and Banking, College of Business, Universiti Utara, Malaysia, Sintok, 06010, Kedah, Malaysia, email: naser_elamroni@yahoo.co.uk (corresponding author)

${ }^{2}$ Department of Civil Engineering and Infrastructure, College of Engineering and Technology, Al Zaytoonah University of Jordan, Amman, Jordan
}

The Engineering Project Organization Journal (C)2017 Engineering Project Organization Society www.epossociety.org 
time and cost limitations (Sears et al., 2008). Construction professionals, such as architects, civil engineers, and quantity surveyors, are the main providers of project management services in the construction industry. These professionals have different training and professional backgrounds and bring their own respective styles and methods while applying project management practices. These often professionals find themselves confronted by issues and undertake additional roles that are not part of their responsibilities (Shenhar et al., 1997). They need to supplement their traditional functions with other non-engineering knowledge and skills to meet the present professional demands while discharging their responsibilities (Ceran \& Dorman, 1995). Hence, to ensure their continued relevance in the industry, project managers rely on various learning activities to fulfill the construction and non-construction specific functions of a project. Identifying the routes and mechanisms by which these project managers acquire such requisite skills should provide options in addressing the training needs of future project managers (Russell et al., 1997). The industry can gain valuable lessons and insights by expanding the scope and coverage of the functions required of project managers by establishing additional skills and knowledge that these practitioners have to acquire continually to retain the marketability of their services (Bentil, 2012). Project managers play a critical role in the success of the construction business. Thus, managerial skills, effectiveness, and construction efficiency can be developed by improving the competencies of project managers, which save cost for the entire country. Palestine can progress in project management when competence components are determined carefully and implemented well to obtain the best results with less risk, achieve success with good quality, and move toward the right direction to establish future goals. This study is the first step toward developing a competence model that will determine the important knowledge and skills of projects managers and enable them to enhance their competence in their assigned tasks. A literature review showed studies concentrated on the skills and attributes of construction project managers. These studies have surveyed practitioners on recommended competencies that each successful manager must incorporate. 
However, studies focusing on the competencies to be mastered by construction project managers that work under critical and confined situations in unstable countries have not been found. This study identifies a list of competencies required by construction project managers in an unstable country with critical and confined situations and provides an exclusive perspective by examining a construction project manager's competencies from a Palestinian industrial point of view.

\section{Literature Review}

Architects, civil engineers, accountants, and building service engineers have become construction project managers. Many construction project managers are not graduates of schools of project management. Few members of an organization's staff are more important to an organization's success than project managers. Their significant position among clients, contractors, and staff requires them to hold a unique set of knowledge and skills (Birnberg, 1992). Project managers in construction are responsible for the overall success of delivering the owner's or client's development needs within the constraints of schedule, cost, and quality and safety requirements. Thus, they play an important role in the operational activities of engineering and architectural construction companies and in additional services and facilities related to the construction industry. From the beginning of the 1990s, business conditions in the construction industry have witnessed unparalleled dynamics as organizations respond to increasing competition within a stagnant or declining market (Gretton, 1993; Chen, 1997). The industry's procurement methods have also changed with clients allocating great risks to contractors (Bedelian, 1996). Within such a changing industry climate, project managers find themselves responsible for the technical components of the project as expressed by construction and engineering accuracy and the reliability of the firm and within-cost performance. Project managers also find themselves standing face to face with new issues and undertaking additional functions and roles that have not been part of their responsibility (Gilleard \& Chong, 1996; Shenhar et al., 1997). Russell et al. (1997) identify this changing role for construction project managers and dispute that they supplement their traditional functions with other "non-engineering" knowledge and skills to meet today's professional requirements. The need for the project management function to adapt to these changing industry situations to maintain its relevance for project delivery into the future is equally emphasized. Many practicing project managers who carry out their duties and roles reflect these skills naturally. For the construction industry, the benefits in concentrating on improving the competency of project managers extract from the effects of such projects on the company's business. Each project creates a significant portion of the company's overall turnover; thus, the failure of a single project can trigger the failure of the entire company (Jannad, 1997; Kangari, 1988). A competence-based approach in education and training sets and provides the opportunity to recognize and develop people with the necessary competencies to perform the job. An organization creates such situations to improve the skills and knowledge of individuals and eventually improve the productivity and competitiveness of the organization itself. Research over the past 40 years has identified several hundred competencies; however, careful inspection often finds a considerable amount of overlap in competency definitions. Twenty to twenty-five competencies typically account for the variance in most jobs (Ryan et al., 2012). This study presents findings from an exploratory study aimed at identifying competencies of the construction project managers in the Palestinian construction industry and how these competencies are used in projects.

\section{Competency: Origin, Concept, and Analysis of the Term}

In the early 1980s, in the U.S., Boyatzis (1982) first used the term "competency" in the managerial context to identify the characteristics that distinguish superior from the average managerial performance. Boyatzis (1982) adopted the term competency, which he described as an underlying characteristic of an individual causally related to effective or superior performance in a job. The study concluded that a range of factors differentiated superior from average performers. 
These factors included personal characteristics, experience, motives, and other different attributes (Wickramasinghe and De Zoyza, 2009). However, some researchers, such as Chung and Wu (2011), cite McClelland's "Testing for Competency rather than for Intelligence" (McClelland, 1973) when mentioning the origin of competency. McClelland proposed the idea of "competency," which differed from the traditional job assessment method based on professional knowledge, personal experiences, or an IQ test. McClelland's definition of competency had been the main driver of the competency movement. Araujo and Taylor (2012) defined competency as any measurable characteristic of a person that differentiates the level of performance in a given job, role, organization, or culture. These learned capabilities are observable and measurable. The International Project Management Association (2006) defined competence as a package of knowledge, attitudes, skills, and relevant experience required to be successful in a particular job. The word comes from the Latin word competentia and "competent" from the Latin word competent. These terms are defined as "to struggle against another" and "to go hand in hand with someone or something." In Spanish, the verbs competir (to compete) and competer (to be responsible for) express the first and second definitions (Dante et al., 2012). Homby and Thomas (1989) defined competency as the knowledge, skills, and qualities needed by effective managers and the ability to perform the functions associated with management in a work situation effectively. Hogg (1993) stated that competencies are the characteristics of a manager that direct to the demonstration of skills and abilities and result in effective performance within an occupational area. From the wide range of related literature, the definition of competency can be summarized as an underlying characteristic of an individual causally related to criterion-referenced effective and/or superior performance in a job or situation. Job competency is a set of behavior patterns that a job incumbent needs to bring to a position to perform its tasks and functions with competence. A job competency can be a motive, trait, skill, selfconcept, body of knowledge, or an attribute that allows an individual to perform a task or activity within a specific function or job (Vichita \& Jintawee, 2007).

\section{Project Management Competencies}

Cheetham and Chivers (2005) have defined precisely the concept of professional project management competence: it is the possession of the range of attributes necessary for effective performance within a profession, and the ability to marshal these consistently to produce the desired overall results. Dante et al. (2012) cited the definition of Gonczi and Athanasou (2004); they indicated that competences can be categorized into three groups: competences as a list of tasks, competences as a collection of attributes, and competencies as a holistic or integrated relationship. Professional project managers working in projects where technical issues are important must have the competency to deal with these issues and problems, they have to be able to identify the issue and be confident that suitable action is taken to deal with them. Project management competencies are achieved by the integration of the skills developed through experience, education and the knowledge acquired during training, and application of such acquired knowledge and experience. The project management competency relates to the capability to manage projects in a professional manner, by applying best practices with regard to the application of project management methods, and the design of the project management process. Project management competencies demand knowledge and experience in the subject, which enables the project to meet its objectives and deadlines (Gareis and Huemann, 1999). Webster and Hillson (2002) mentioned five core elements of competency which are: personal characteristics, experience, attitude, knowledge, and skills. Before them, Morris (1994) mentioned the principal competencies of a project manager, which are: (1) skills in project management methods and tools; (2) knowledge and awareness of project environment; (3) basic business and management skills; (4) team and people skills; (5) knowledge of project sponsor role; (6) technical knowledge; and (7) Integrative abilities of the above skills and knowledge. Cheng et al. (2005) propose that, in addition to competencies and competencies managerial performance also requires the enactment of a role which emerges through social interaction with others at work. Competency is 


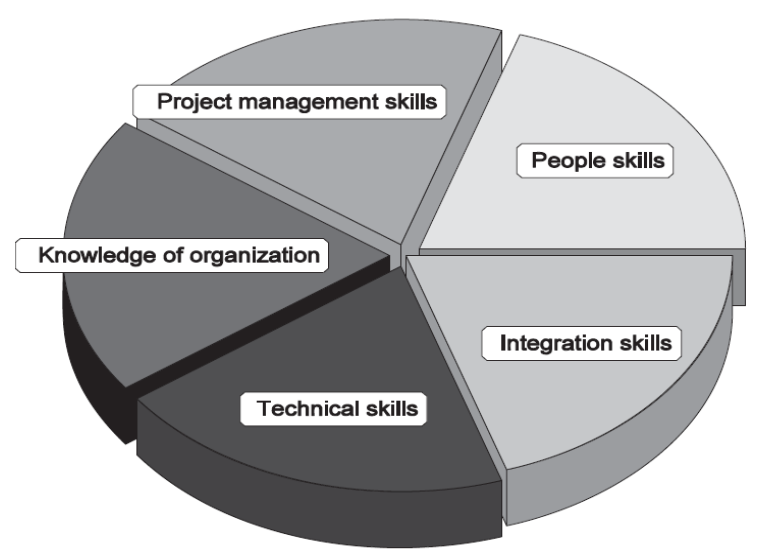

Figure 1. Basic Project Manager Skills (Richmann 2011)

demonstrated in the ability to effectively manage the varying perceptions and expectations of others.

\section{Requirements for Project Managers Competencies}

In fulfilling the demanded construction and the non-construction functions, construction project managers often depend on various learning activities that help identify the routes and mechanisms; these construction project managers acquire requisite skills that provide pathways for addressing the training needs of future construction project managers (Kangari, 1988). Richmann (2011) stated that to be successful; a project manager needs to be strong in five areas. These areas are shown in Figure (1).

Chen and Partington (2006) used a phenomenographic research approach to determine that construction project managers (CPMs) conceived construction project management as: planning and controlling, organising and coordinating, and predicting and managing potential problems. These concepts were converted into key competencies that CPMs needed to accomplish construction activities. For instance, four abilities are needed to understand planning and control; these include the ability to plan, having adequate knowledge of construction, the ability to communicate and the ability to manage a team. Although project managers generally remain firmly focused on the traditional "objective" or "hard" perspective, there is an increasing focus on the more "subjective" or "softer" factors that are regarded as essential to all professional endeavours (Ingason and Jónasson, 2009). Other studies have attempted to apply well-established conceptual frameworks from other disciplines (e.g., HRM) to explore the project managers' competencies profile. For instance, Ahadzie et al. (2008) argued that a contextual-task model has empirical relevance for application in project-based sectors of the construction industry where the relative abilities of construction project manager were identified. Their study highlighted Project managers' soft skills (viewed as Contextual Performance Behaviours) as more critical predictors of Project managers' performance than hard skills (viewed as Task Performance Behaviours). Cheng et al. (2005) assessed both the Project managers' behavioural competencies and the job task competencies that contribute to the Project managers' superior performance within the construction industry. Their results indicated that job-task competencies are highly specific to the industry in which they work, and that the behavioural competencies of Project managers are mostly generic in nature. Project Management Institute (PMI), (2013) in their last version of PMBOK state that effective project management requires that the project manager possess the following competencies: Knowledge, Performance and Personal. Also, PMI (2013) stated effective project managers require a balance of ethical, interpersonal, and conceptual skills that help them analyze situations and interact appropriately, these important interpersonal skills such as: Leadership, Team building, Motivation, Communication, Influencing, Decision making, Political and cultural awareness, Negotiation, Trust building, Conflict management, and Coaching. According to Edum \& McCaffer (2000), the project managers should have Essential Project Management Knowledge and Skills, and they stated that the professional competency in project management is achieved by the combination of knowledge obtained during training, and skills developed through experience and the application of the obtained knowledge.

Many previous studies have tried hard to come up with a model to identify the competencies needed 
by project managers. However, these attempts did not give a general and a comprehensive model through which to measure and identify competencies needed by project managers. This is one of the gaps in these studies, and this research will attempt to bridge this gap. There is another observation that has not been addressed in the previous research and will be addressed by the current research, it is finding a comprehensive model for the competencies of project managers working under conditions that can be described as the worst in the world, as the project managers work in a country that is suffered from military occupation, economic and social problems.

\section{Research Method}

About 187 competencies of project managers were collected from in-depth literature review from different international researches together with some interviews with project managers and scholars who are concerned of the construction sector in Palestine (Table 1). These competencies were grouped into four competency groups according to Cheetham \& Chivers (1996), these groups are: knowledge/cognitive competence, values/ethical competence, personal/behavioral competence and functional competence. A questionnaire survey using the 204 competencies was designed to identify the competence components of project managers in Palestine. The survey instrument was a person-administrated. One format was used in the questionnaire which is the checklist. The questionnaire contained three sections. First section was focused on the respondent's firm information, which includes: name of the firm, firm speciality, number of employees in the firm, and the firm nationality. The second section concentrated on respondent's personal information, which include: current position in the firm, academic qualification, education background, age, gender, nationality, years of experience prior to attaining project managers, years of experience spent as project managers, number of current projects responsible for, number of projects responsible for since becoming project managers, while the last section listed project manager`s competence items, respondents were asked to indicate the degree of importance of these competencies using Likert scale. The questionnaire was translated into the Arabic language from the English version, and this was done to assist the respondents in answering the questionnaire with more clear understanding as some of them are not good in using English language. The data was collected using the postal technique. It took on an average approximately less than 5 minutes for the participants to complete it. The targeted population of this study was the contractors and consultants project managers working in the construction industry in Palestine (west bank). Because of the difficulties of collecting data from all cities of Palestine because of the political situation $\&$ the closure of cities and roads, the researchers selected three cities that could represent the Palestinian construction industry; these cities are: Nablus, Tulkarm, and Jenin. The targeted contractors and consultants' firms in these cities have a valid registration in the Palestinian Contractors Union (PCU) and in the Palestinian Engineers Association (PEA) in 2011 in all types of construction fields that include: buildings, roads, water and sewage, and public works. Based on the data obtained from PCBS (2011) regarding the numbers of Palestinian`s contractors and consultants, the total population of this research was 402. A simple random sampling was adapted, which represents the whole practicing project managers working in construction companies in the selected Palestinian cities. 150 questionnaires were sent to the construction companies, sometimes face-to-face deliveries of the questionnaires are used to promote respondents and raise response rate in addition to the personal contacts of the contractors and consultants. 96 questionnaires were returned which all respondents were project managers, yielding a response rate of 64 percent. Statistical Package for Social Sciences (SPSS) Version 18.0, Microsoft Excel version 2013, The Partial Least Squares (PLS) procedure and structural equation modeling (SEM) tool (Smart-PLS 3.0) was used to analyze the data for this study. Finally, relative importance index RII was implemented to achieve the other objective. 
Table 1 Sources of the questionnaire variables in the research

\begin{tabular}{|c|c|c|}
\hline Variable & Dimension & Source \\
\hline \multirow{7}{*}{$\begin{array}{l}\text { Knowledge } \\
\text { Competence }\end{array}$} & Technical Knowledge & $\begin{array}{l}\text { Edum-Fotwe \& McCaffer (2000), Nicholas \& Steyn } \\
\text { (2012), Tripathi \& Suri (2010), Mahmood et al. (2006) }\end{array}$ \\
\hline & $\begin{array}{l}\text { Management } \\
\text { Knowledge }\end{array}$ & $\begin{array}{l}\text { Edum-Fotwe \& McCaffer (2000), Tripathi \& Suri } \\
\text { (2010), Mahmood et al. (2006), Webster \& Hilson } \\
\text { (2002), Pinto \& Trailer (1998), Mahmood et. al (2006) }\end{array}$ \\
\hline & $\begin{array}{l}\text { Communication } \\
\text { Knowledge }\end{array}$ & $\begin{array}{l}\text { Edum-Fotwe \& McCaffer (2000), Chung \& Wu } \\
\text { (2011), Tripathi \& Suri (2010), Mahmood et al. (2006), } \\
\text { Webster \& Hilson (2002). }\end{array}$ \\
\hline & Computer Knowledge & $\begin{array}{l}\text { Edum-Fotwe \& McCaffer (2000), Mahmood et al. } \\
\text { (2006) }\end{array}$ \\
\hline & Financial Knowledge & $\begin{array}{l}\text { Edum-Fotwe \& McCaffer (2000), Mahmood et al. } \\
\text { (2006) }\end{array}$ \\
\hline & Legal Knowledge & $\begin{array}{l}\text { Edum-Fotwe \& McCaffer (2000), Mahmood et. al } \\
\text { (2006), Webster \& Hilson (2002) }\end{array}$ \\
\hline & General Knowledge & $\begin{array}{l}\text { Edum-Fotwe \& McCaffer (2000), Mahmood et al. } \\
\text { (2006), Chung \& Wu (2011), Tripathi \& Suri (2010) }\end{array}$ \\
\hline \multirow{7}{*}{$\begin{array}{l}\text { Functional } \\
\text { Competence }\end{array}$} & $\begin{array}{l}\text { Organize Project } \\
\text { Initiations }\end{array}$ & Mahmood et al. (2006); CIDB (2002) \\
\hline & Develop Project Plan & Mahmood et al. (2006); CIDB (2002) \\
\hline & $\begin{array}{c}\text { Manage Human } \\
\text { Resources Functions }\end{array}$ & Mahmood et al. (2006); CIDB (2002) \\
\hline & $\begin{array}{l}\text { Manage Project } \\
\text { Quality, Health, Safety } \\
\text { \& Environment }\end{array}$ & Mahmood et al. (2006); CIDB (2002) \\
\hline & $\begin{array}{c}\text { Manage Design } \\
\text { Development \& } \\
\text { Contract } \\
\text { Administration }\end{array}$ & Mahmood et al. (2006); CIDB (2002) \\
\hline & $\begin{array}{l}\text { Manage Project } \\
\text { Tracking \& } \\
\text { Controlling System }\end{array}$ & Mahmood et al. (2006); CIDB (2002) \\
\hline & $\begin{array}{l}\text { Administer Project } \\
\text { Close-out }\end{array}$ & Mahmood et al. (2006); CIDB (2002) \\
\hline \multirow{2}{*}{$\begin{array}{l}\text { Personal or } \\
\text { Behavioral } \\
\text { Competence }\end{array}$} & Social / Vocational & $\begin{array}{l}\text { Cheetham \& Chivers (1996), Chung \& Wu (2011), } \\
\text { Mahmood et al. (2006), Webster \& Hilson (2002), } \\
\text { Pinto \& Trailer (1998), Nicholas \& Steyn (2012) }\end{array}$ \\
\hline & Intraprofessional & $\begin{array}{l}\text { Cheetham \& Chivers (1996), Chung \& Wu (2011), } \\
\text { Mahmood et al. (2006), Webster \& Hilson (2002), } \\
\text { Nicholas \& Steyn (2012), Tripathi \& Suri (2010) }\end{array}$ \\
\hline \multirow{2}{*}{$\begin{array}{l}\text { Values / } \\
\text { ethical } \\
\text { Competence }\end{array}$} & Personal & $\begin{array}{l}\text { Cheetham \& Chivers (1996), Mahmood et al. (2006), } \\
\text { Pinto \& Trailer (1998), Chung \& Wu (2011), Nicholas } \\
\text { \& Steyn (2012), Webster \& Hilson (2002) }\end{array}$ \\
\hline & Professional & $\begin{array}{l}\text { Cheetham \& Chivers (1996), Mahmood et al. (2006), } \\
\text { Webster \& Hilson (2002), Muller \& Turner (2010) }\end{array}$ \\
\hline
\end{tabular}




\section{Results and Discussion}

\section{Background of the Construction Firms}

Table (2) indicates the background of the construction firms where the respondents' attached. It was found that 65.6 percent of the firms were consulting firms, and 34.4 percent were contracting firms. The reason for the big difference in the response rate between both firms could be that the contracting firms have less number of project managers staff compared to consulting firms, another reason noticed by the researcher is the great interest and cooperation of project managers with the study if compared with contracting project managers. Also, Table (2) shows that most of Palestinian construction firms are small with less than 20 employees (76\%), 5.3 percent of the firms have 21 to 40 employees, 41 to 60 employees $(6.2 \%)$ and more than 60 employees $(12.5 \%)$, this result could be explained by the small number and size of the construction projects in Palestine, another main reason is that a project manager can manage several projects at the same time.

Table 2 Background of the firms

\begin{tabular}{|l|c|c|}
\hline \multicolumn{1}{|c|}{ Variable } & Frequency & Percentage \\
\hline \multicolumn{2}{|l|}{ Type of the organization } \\
\hline Consulting & 63 & $65.6 \%$ \\
\hline Contracting & 33 & $34.4 \%$ \\
\hline No. of employees \\
\hline$<20$ & 73 & $76 \%$ \\
\hline 21 to 40 & 5 & $5.3 \%$ \\
\hline 41 to 60 & 6 & $6.2 \%$ \\
\hline$>60$ & 12 & $12.5 \%$ \\
\hline
\end{tabular}

\section{Background of the Respondents}

Table (3) shows the distribution of the respondents according to their demographic background. 94.8 percent of the respondents hold engineering qualification; this result made the research goal easy as we are dealing with well-qualified and educated people, this results inconsistent with the results from Edum-Fotwe \& McCaffer (2000) in the UK construction sector. Approximately 86.5 percent of the respondents were bachelor degree holders, master's degree (10.4\%) and 3.1 percent have no formal education. Majority of the respondents were male $(81.3 \%$ ) and aged between 31 to 40 years old $(42.7 \%)$, this means a medium period of experience needed in order to attain the status of construction project manager within the Palestinian construction sector. $97.9 \%$ were Palestinian, and $2.1 \%$ were Jordanian, this indicates that the construction projects in Palestine handled by the Palestinians. This could be explained by the small size of the Palestinians firms, the small size of projects, the political situation of Palestine, and finally the availability of qualified Palestinian construction project managers. The construction project managers in the Palestinian construction industry $(47.9 \%)$ have more than 10 years working experience prior attaining the position of project manager, $18.8 \%$ have $11-20$ years, and $10.4 \%$ more than 21 years. According to these results one could conclude that it is easy for Palestinian engineers to get the position of project managers, this could be clarified by the fact that the construction projects are small in size, they are not complicated, most projects have the same nature (small to medium residential buildings), and small size of construction firms. In their current position as project manager, about 21.9 percent of the respondents have 1 to 3 years of experience as project manager, 4 to 6 years $(22.9 \%)$ and 7 to 10 years $(17.7 \%), 37.5$ percent of the respondents were worked as project manager for more than 10 years. This result gives a good indication that the survey was executed on construction project managers with moderate to high experience. Currently $42.7 \%$ of the Palestinian construction project managers managing more than 5 projects, and $57.3 \%$ of them managing less than five projects; this result was expected and might be explained by the small size of the construction projects, simplicity and repetition of the projects, and the construction project manager can manage and follow up several projects without the presence of authoritarian rule or law governing this phenomenon. Approximately the same result is repeated on the number of projects managed by respondents since attaining project manager status, $30.2 \%$ have managed 1-5 projects, $7.3 \%$ have managed from 6 to 10 projects, $13.5 \%$ have managed $11-20$ projects, and $49 \%$ 
Table 3 Background of the respondents

\begin{tabular}{|c|c|c|}
\hline Variable & Frequency & Percentage \\
\hline \multicolumn{3}{|c|}{ Academic qualification } \\
\hline Engineering & 92 & $94.8 \%$ \\
\hline Diploma & 2 & $2.1 \%$ \\
\hline No Formal & 2 & $3.1 \%$ \\
\hline \multicolumn{3}{|c|}{ Education background } \\
\hline Bachelor degree & 82 & $86.5 \%$ \\
\hline Master's & 10 & $10.4 \%$ \\
\hline None & 4 & $3.1 \%$ \\
\hline \multicolumn{3}{|l|}{ Age } \\
\hline$<30$ years old & 15 & $15.6 \%$ \\
\hline 31 to 40 years old & 41 & $42.7 \%$ \\
\hline 41 to 50 years old & 15 & $15.7 \%$ \\
\hline$>50$ years old & 25 & $26 \%$ \\
\hline \multicolumn{3}{|l|}{ Gender } \\
\hline Male & 78 & $81.3 \%$ \\
\hline Female & 18 & $18.8 \%$ \\
\hline \multicolumn{3}{|l|}{ Nationality } \\
\hline Palestinian & 94 & $97.9 \%$ \\
\hline Jordanian & 2 & $2.1 \%$ \\
\hline \multicolumn{3}{|c|}{$\begin{array}{l}\text { Working experience prior to attaining } \\
\text { project manager }\end{array}$} \\
\hline $1-5$ years & 32 & $33.3 \%$ \\
\hline $6-10$ years & 18 & $18.8 \%$ \\
\hline $11-20$ years & 36 & $37.5 \%$ \\
\hline More than 21 years & 10 & $10.4 \%$ \\
\hline \multicolumn{3}{|c|}{ Experience as project manager } \\
\hline $1-3$ years & 21 & $21.9 \%$ \\
\hline 4-6 years & 22 & $22.9 \%$ \\
\hline $7-10$ years & 17 & $17.7 \%$ \\
\hline More than 10 years & 36 & $37.5 \%$ \\
\hline \multicolumn{3}{|c|}{$\begin{array}{l}\text { Current number of projects managed by the } \\
\text { respondent }\end{array}$} \\
\hline 1 & 14 & $14.6 \%$ \\
\hline $2-3$ & 29 & $30.2 \%$ \\
\hline $4-5$ & 12 & $12.5 \%$ \\
\hline More than 5 & 41 & $42.7 \%$ \\
\hline \multicolumn{3}{|c|}{$\begin{array}{l}\text { Number of projects managed by respondent } \\
\text { since attaining manager status }\end{array}$} \\
\hline $1-5$ & 29 & $30.2 \%$ \\
\hline $6-10$ & 7 & $7.3 \%$ \\
\hline $11-20$ & 13 & $13.5 \%$ \\
\hline More than 21 & 47 & $49 \%$ \\
\hline
\end{tabular}

have managed more than 21 construction projects. Moreover, as shown in Figure (2), 35\% of the respondents are construction project managers, $22 \%$ are general managers, and the other positions percentages range between $2-11 \%$. It is important to clarify that despite different respondents' positions indicated, the respondents indicated their current positions at the time of survey, and that does not mean that they had not worked as project manager previously. To confirm this, the researchers asked the respondents about their current and previous positions during the follow-up stage, and all of them stated that they had worked as construction project manager. This result could be explained by the facts that most of construction project sizes in Palestine are small, simple, repeated, and the size of the construction firms are small to medium size as shown in Table (1) above. To sum up, the respondents of this research are currently managing and running many construction projects at the same time, and they have many cumulative numbers of projects since becoming project managers. Therefore, we are talking about highly qualified construction project managers

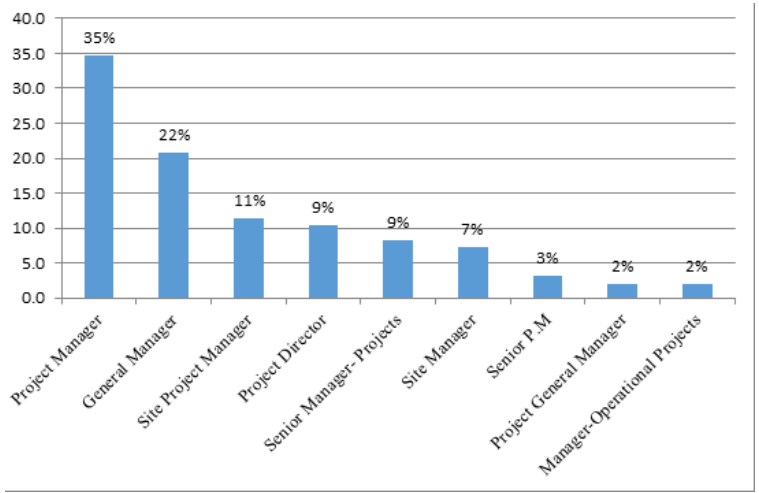

Figure 2. Distribution of staff performing project management function by designation

with highly practical experience and high position.

\section{Results and Discussion of the Validity Test}

This section of the analysis was attempted to identify the competence components of the construction project managers in the Palestinian construction industry. The researchers conducted a Confirmatory Factor Analysis (CFA) on all items measuring the competence dimensions to validate the used construction project managers competence scale in terms of convergent and discriminant validity (Worthington \& Whittaker, 2006). Convergent validity testifies whether the multiple items designed to measure the same 
concept are in agreement. As suggested by Hair et al. (2010), this study used the factor loadings, composite reliability and Average Variance Extracted (AVE) to assess convergent validity. Standardized factor loading denotes the correlation between the variables and the factors. Meanwhile, AVE is a measure of convergence among a set of items representing a latent construct in Structural Equation Modeling (SEM). It is computed as an average percentage of variance explained among the items of a construct (Hair et al., 2010). Composite reliability refers to a measure of reliability and internal consistency of the items that represent a latent construct in SEM. Discriminant validity is the extent to which a construct is truly distinct from other constructs by empirical standards (Hair et al., 2013). The discriminant validity is fundamentally justified based on the existence or non-existence of cross-loading between the constructs, between- and withinconstruct error variance (Hair et al., 2010). FornellLarcker approach is used to assess the discriminant validity of the scale. Discriminant validity is satisfied when the square root of the Average variance extracted (AVE) values from the component is greater than the variance any of the inter-component correlations (Hair et al., 2013). Based on the multidimensionality of the competence construct, it has been modeled as a higher-order construct in a reflective-reflective way (Ringle et al., 2012). Each item was modeled as a reflective indicator of one of the eighteen first-order constructs. Following the indicatorrepeated approach (Wetzels et al., 2009), each item as a reflective indicator of the relevant higher-order constructs was modeled. The repeated approach for modeling higherorder construct models was required because all latent variables in a structural equation model, which includes higherorder constructs, must have a measurement model with at least one indicator (Ringle et al., 2012). Thus, each of the eighteen first-order constructs as reflective constructs were modeled as one of the four second-order constructs. In turn, the secondorder constructs are reflective to the third-order construct "Professional Competence". Thus, the measurement instrument was modeled as a hierarchical component model with reflective indicators and reflective (sub)-constructs. Based on CFA, it has been used the estimated factor scores to estimate each second-order model separately first, then the overall model simultaneously. Measurement model assessment will be applied on the first-order constructs and their relevant second-order construct consequently. Current model consists of four groups of secondorder constructs which are; knowledge competence, functional competence, personal competence, and values competence. Following is the Measurement model assessment on the firstorder constructs and their relevant second-order construct.

\section{Knowledge Competence}

Knowledge competence constructs consist of seven first-order constructs, namely, technical knowledge, management knowledge, general knowledge, communication knowledge, computer knowledge, financial knowledge, and legal knowledge. Smart PLS 3.0 validated the knowledge competence dimension in terms of

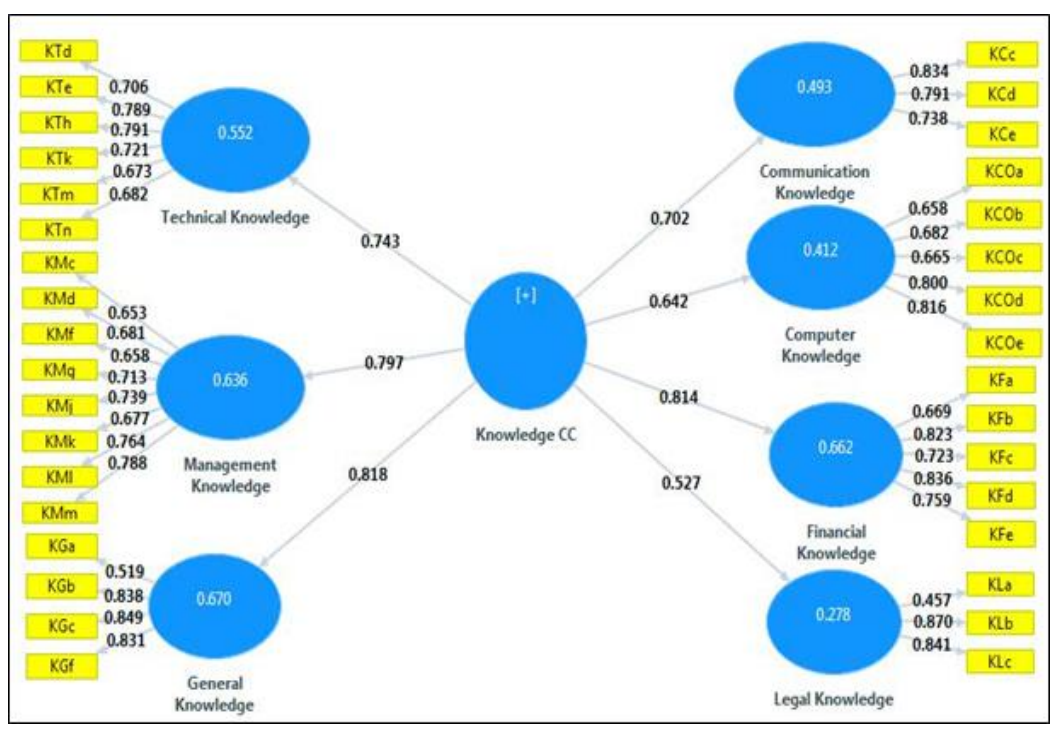

Figure 3. Knowledge Competence Factor Loadings

The Engineering Project Organization Journal

(C)2017 Engineering Project Organization Society www.epossociety.org 
Table 4 Results Summary of Item Loading, AVE and Composite Reliability of the Knowledge Competence Construct

\begin{tabular}{|c|c|c|c|c|}
\hline Construct & Items & $\begin{array}{c}\text { Main } \\
\text { loading }\end{array}$ & AVA & $\begin{array}{l}\text { Composite } \\
\text { Reliability }\end{array}$ \\
\hline \multirow{3}{*}{$\begin{array}{l}\text { Communication } \\
\text { Knowledge }\end{array}$} & Interpersonal understanding $\mathrm{KCc}$ & 0.834 & 0.622 & 0.831 \\
\hline & Council team members KCd & 0.791 & & \\
\hline & Verbally and in writing at all levels $\mathrm{KCe}$ & 0.738 & & \\
\hline \multirow{5}{*}{$\begin{array}{l}\text { Computer } \\
\text { Knowledge }\end{array}$} & Operating systems KCOa & 0.658 & 0.530 & 0.848 \\
\hline & E-mail and internet (web) $\mathrm{KCOb}$ & 0.682 & & \\
\hline & Spreadsheet and word KCOc & 0.665 & & \\
\hline & CAD KCOd & 0.801 & & \\
\hline & Project management softwares KCOe & 0.816 & & \\
\hline \multirow{5}{*}{$\begin{array}{l}\text { Financial } \\
\text { Knowledge }\end{array}$} & Reporting systems $\mathrm{KFa}$ & 0.669 & 0.584 & 0.875 \\
\hline & Project finance arrangement $\mathrm{KFb}$ & 0.823 & & \\
\hline & Investment appraisal KFc & 0.723 & & \\
\hline & Auditing KFd & 0.836 & & \\
\hline & Establishing budgets $\mathrm{KFe}$ & 0.759 & & \\
\hline \multirow{4}{*}{$\begin{array}{l}\text { General } \\
\text { Knowledge }\end{array}$} & Public relations $\mathrm{KGa}$ & 0.519 & 0.596 & 0.851 \\
\hline & Understanding of organization $\mathrm{KGb}$ & 0.838 & & \\
\hline & Customer service KGc & 0.849 & & \\
\hline & Coaching and training KGf & 0.831 & & \\
\hline \multirow{3}{*}{$\begin{array}{l}\text { Legal } \\
\text { Knowledge }\end{array}$} & General legal background KLa & 0.457 & 0.558 & 0.780 \\
\hline & Drafting contracts KLb & 0.870 & & \\
\hline & Health and safety issues KLc & 0.841 & & \\
\hline \multirow{8}{*}{$\begin{array}{l}\text { Management } \\
\text { Knowledge }\end{array}$} & Decision-making KMc & 0.653 & 0.505 & 0.890 \\
\hline & Negotiation KMd & 0.681 & & \\
\hline & Record management $\mathrm{KMg}$ & 0.658 & & \\
\hline & Human behavior $\mathrm{KMg}$ & 0.713 & & \\
\hline & Team working KMj & 0.739 & & \\
\hline & Top management relations KMk & 0.677 & & \\
\hline & Team building KMl & 0.764 & & \\
\hline & Establish effective working relationships $\mathrm{KMm}$ & 0.788 & & \\
\hline \multirow{6}{*}{$\begin{array}{l}\text { Technical } \\
\text { Knowledge }\end{array}$} & Integrate concepts from different fields $\mathrm{KTd}$ & 0.706 & 0.531 & 0.871 \\
\hline & Technical writing KTe & 0.789 & & \\
\hline & Construction management activities KTh & 0.791 & & \\
\hline & Productivity and cost control KTk & 0.721 & & \\
\hline & Plant hire and management KTm & 0.673 & & \\
\hline & Quality control KTn & 0.682 & & \\
\hline \multirow{7}{*}{$\begin{array}{l}\text { Knowledge } \\
\text { competence } \\
\text { (second order } \\
\text { construct) }\end{array}$} & Technical Knowledge & 0.743 & 0.587 & 0.939 \\
\hline & Management Knowledge & 0.797 & & \\
\hline & General Knowledge & 0.818 & & \\
\hline & Communication Knowledge & 0.702 & & \\
\hline & Computer Knowledge & 0.642 & & \\
\hline & Financial Knowledge & 0.814 & & \\
\hline & Legal Knowledge & 0.527 & & \\
\hline
\end{tabular}

convergent and discriminant validities (Ringle et al., 2014). Figure (3) shows that the items were deleted one by one. PLS algorithm was rerun to check the loading of the items. Loading below 0.4 was deleted immediately. Loading above 0.4 was scrutinized to determine whether it should be deleted or retained for theoretical purposes. Some items with low loading were deleted to increase the 
average variance extracted (AVE) value to above 0.5 . Figure (3) shows the valid items that satisfied the convergent validity of the first-order knowledge competence constructs.

Table (4) shows the AVE and Composite Reliability of the knowledge competence construct. These values were found satisfied, and the convergent validity of knowledge competence construct was achieved.

The discriminant validity of the scales is satisfied when the square root of the AVE values from the component is greater than the variance any of the inter-component correlations based on the standards recommended by Fornell and Larcker (1981). The AVE values on the diagonal are greater than the correlation coefficient of that component with all other components in the knowledge competence construct (Table 5). Discriminant validity was fulfilled for all components and thus, the measurements satisfy the criteria recommended by Hair et al. (2013). These results provide strong empirical support for the convergent and discriminant validities of the knowledge competence construct used in the research. Knowledge competence items have been accomplished by running bootstrapping procedure. The $\mathrm{T}$ value was assessed for the standardized path coefficients by running bootstrapping with 5000 resamples using Smart PLS 3.0, as suggested by Hair et al. (2013). Critical values for a one-tailed test were assumed as the following: $t$ value $\geq 1.645$ at a significance level of $5 \%, t$ value $\geq 2.326$ at a significance level of $1 \%$, and $t$ value $\geq 3.091$ at a significance level of $0.1 \%$ (Hair et al., 2013). The results agree with Edum-Fotwe and McCafer's (2000) study. They obtained previous competencies in their study, and their survey established that the knowledge and skills necessary to maintain project managers' competency to fulfill these changing demands are acquired largely from experiences. Dogbegah et al. (2011) included different competencies in their model and used knowledge management as one of the main competencies in their developed model. The results agreed with the competency model for project managers in the Libyan construction industry developed by Omran et al. (2012), which contained knowledge competence with four constituents. Hwang and $\mathrm{Ng}$ (2013) examined the competency of project managers in the context of green construction. They identified different critical management knowledge areas in their model. A comparative analysis of some engineering competencies distinguished and identified by several accreditation agencies of the USA, the UK, Australia, Japan, and Singapore was carried out by Goel (2006). Significant similarities in the competency set identified by these accreditation agencies and among the core competencies are selected namely, technical competence and communication skills. Male et al. (2011) studied the generic competencies required by engineers, which included technical and non-technical items, and found that the communication competency factor was the highest important factor among 11 factors identified to the work of engineers. They also concluded that technical competencies were rated with relatively low importance for the most technical items. Tripathi and Sure (2010)

Table 5 Correlations and discriminant validity of knowledge competence construct

\begin{tabular}{|l|c|c|c|c|c|c|c|}
\hline & 1 & 2 & 3 & 4 & 5 & 6 & 7 \\
\hline 1 Communication Knowledge & $\mathbf{0 . 7 8 9}$ & & & & & & \\
\hline 2 Computer Knowledge & 0.300 & $\mathbf{0 . 7 2 8}$ & & & & & \\
\hline 3 Financial Knowledge & 0.397 & 0.684 & $\mathbf{0 . 7 6 4}$ & & & & \\
\hline 4 General Knowledge & 0.556 & 0.542 & 0.646 & $\mathbf{0 . 7 7 2}$ & & & \\
\hline 5 Legal Knowledge & 0.185 & 0.449 & 0.565 & 0.431 & $\mathbf{0 . 7 4 7}$ & & \\
\hline 6 Management Knowledge & 0.671 & 0.270 & 0.429 & 0.536 & 0.184 & $\mathbf{0 . 7 1 1}$ & \\
\hline 7 Technical Knowledge & 0.465 & 0.203 & 0.477 & 0.484 & 0.276 & 0.667 & $\mathbf{0 . 7 2 9}$ \\
\hline
\end{tabular}

Note: Square root of the AVE on the diagonal 
developed a competency-based management and performance assessment system for academic management; the developed model consisted of three competencies, one of which is the knowledge competence. Boyatzis (2008) mentioned three clusters of competencies that differentiated outstanding from average performers in many countries; one of these clusters is cognitive competencies. PMI (2013) divided project management competencies into three separate dimensions; the first one is knowledge competency. PMI (2013) defined it as a project manager's knowledge on the application of the process, tools, and techniques for project activities. Each project management competency is demonstrated by different means. Knowledge competency is achieved when the project manager passes an appropriate credential assessment, such as PMP examination or an accredited international project manager examination. Spencer and Spencer (1993) defined the five characteristics of competency. Knowledge and skills can be assessed and developed through training and experience.

\section{Functional Competence}

Functional competence constructs consists of seven first-order constructs, namely, organizing project initiations, developing project plans, managing human resource functions, managing project quality health safety and environment,

handling design development and contract admin, tracking and controlling system, and administering project close out. Figure (4) shows that the deletion of the items was performed gradually. PLS algorithm ran after each deletion to check the loading of the items. Some items with low loading were deleted to increase AVE value to above 0.5. Figure (4) shows the valid items that satisfied the convergent validity of the first-order constructs.

Table (6) shows in detail the item loading, AVE, and composite reliability of the functional competence construct. These values were satisfactory; thus, the convergent validity of functional competence construct was achieved.

Table (7) shows that the AVE values on the diagonal are greater than the correlation coefficient of that component with all other components in the functional competence construct. Thus, the discriminant validity was fulfilled for all components, and the measurements satisfy the criteria recommended by Hair et al. (2013). These results provide strong empirical support for the convergent and discriminant validities of the functional competence construct used in the research.

Functional competence items have been validated by running the bootstrapping procedure. $T$ value was assessed for the standardized path coefficients by running bootstrapping with 5000 resamples using smart PLS 3.0, as

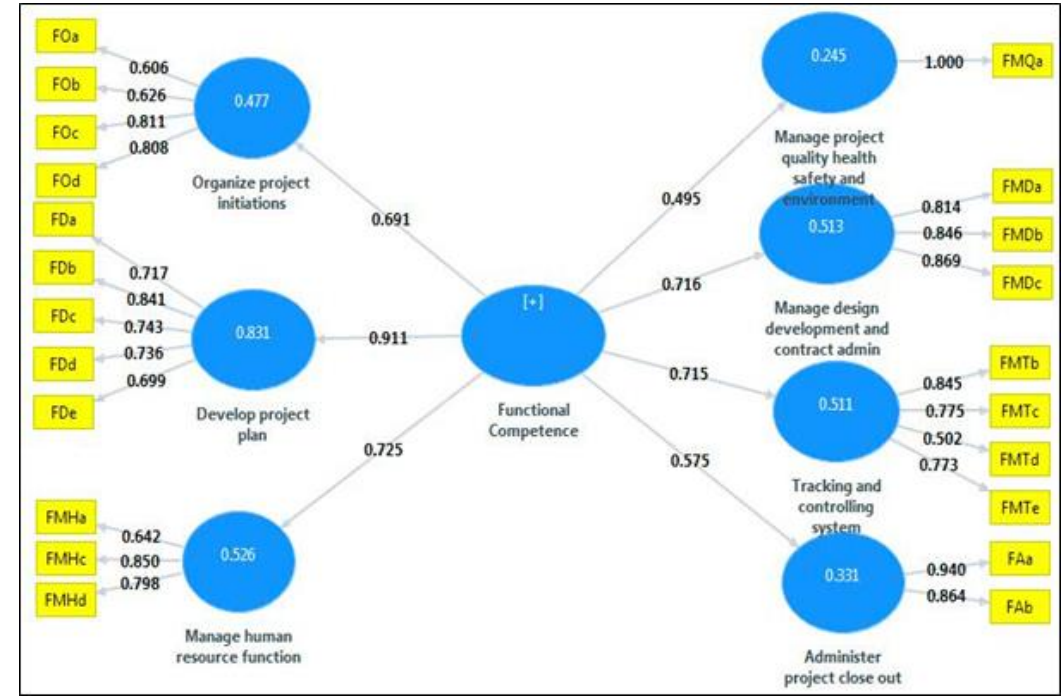

Figure 4. Functional Competence Factor Loadings suggested by Hair et al. (2013). Cheetham and Chivers (1998) stated that functional competence was an important component of professional competence and considered that it merited a key place within their holistic model. They divided functional competence to four components, namely, occupation-specific, organization process, cerebral, and psychomotor. The results agree with the CIDB (2002) report, which had the same dimensions for project manager's competencies. Posner (1987) stated that the

The Engineering Project Organization Journal (C)2017 Engineering Project Organization Society www.epossociety.org 
Table 6 Results Summary of Item Loading, AVE and Composite Reliability of the Functional Competence Construct

\begin{tabular}{|c|c|c|c|c|}
\hline Construct & Item & $\begin{array}{c}\text { Main } \\
\text { loading }\end{array}$ & AVE & $\begin{array}{l}\text { Composite } \\
\text { Reliability }\end{array}$ \\
\hline $\begin{array}{l}\text { Administer project } \\
\text { close out }\end{array}$ & Organize completion \& handover activities FAa & 0.940 & 0.815 & 0.898 \\
\hline \multirow{6}{*}{$\begin{array}{l}\text { Develop project } \\
\text { plan }\end{array}$} & Perform contract closure processes FAb & 0.864 & & \\
\hline & Establish project organizational structure FDa & 0.717 & 0.561 & 0.864 \\
\hline & $\begin{array}{l}\text { Establish project monitoring and control system } \\
\text { FDb }\end{array}$ & 0.841 & & \\
\hline & Prepare risk management plan FDc & 0.743 & & \\
\hline & Establish project budget FDd & 0.736 & & \\
\hline & $\begin{array}{l}\text { Establish information \& communication system } \\
\text { FDe }\end{array}$ & 0.699 & & \\
\hline \multirow{3}{*}{$\begin{array}{l}\text { Manage design } \\
\text { development and } \\
\text { contract admin }\end{array}$} & Coordinate design development process FMDa & 0.814 & 0.711 & 0.881 \\
\hline & Coordinate statutory requirements FMDb & 0.846 & & \\
\hline & Monitor tender documentation FMDc & 0.869 & & \\
\hline \multirow{3}{*}{$\begin{array}{l}\text { Manage human } \\
\text { resource function }\end{array}$} & Plan human resources requirements FMHa & 0.642 & 0.591 & 0.810 \\
\hline & $\begin{array}{l}\text { Coordinate/manage project team activities } \\
\text { FMHc }\end{array}$ & 0.850 & & \\
\hline & $\begin{array}{l}\text { Identify \& administer interpersonal conflict } \\
\text { FMHd }\end{array}$ & 0.798 & & \\
\hline $\begin{array}{lr}\text { Manage } & \text { project } \\
\text { quality } & \text { health } \\
\text { safety } & \text { and } \\
\text { environment } & \\
\end{array}$ & $\begin{array}{l}\text { Establish , implement and monitor quality, } \\
\text { health, safety \& environmental plan FMQa }\end{array}$ & - & & \\
\hline \multirow{4}{*}{$\begin{array}{l}\text { Organize project } \\
\text { initiations }\end{array}$} & Prepare project charter/memorandum FOa & 0.607 & 0.518 & 0.808 \\
\hline & Prepare project brief/client`s objectives FOb & 0.626 & & \\
\hline & Conduct project feasibility study FOc & 0.811 & & \\
\hline & Establish project organization strategy FOd & 0.808 & & \\
\hline \multirow{4}{*}{$\begin{array}{l}\text { Tracking and } \\
\text { controlling system }\end{array}$} & Control project cost/budget FMTb & 0.845 & 0.541 & 0.820 \\
\hline & Administer progress reporting system FMTc & 0.775 & & \\
\hline & Administer variations/changes FMTd & 0.502 & & \\
\hline & Administer dispute resolution FMTe & 0.773 & & \\
\hline \multirow{7}{*}{$\begin{array}{l}\text { Functional } \\
\text { Competence } \\
\text { (Second order } \\
\text { construct) }\end{array}$} & Organize project initiations & 0.691 & 0.858 & 0.909 \\
\hline & Develop project plan & 0.911 & & \\
\hline & Manage human resource function & 0.725 & & \\
\hline & $\begin{array}{l}\text { Manage project quality health safety and } \\
\text { environment }\end{array}$ & 0.495 & & \\
\hline & Manage design development and contract admin & 0.716 & & \\
\hline & Tracking and controlling system & 0.715 & & \\
\hline & Administer project close out & 0.575 & & \\
\hline
\end{tabular}


Table 7. Correlations and discriminant validity of functional competence construct

\begin{tabular}{|l|l|l|l|l|l|l|l|}
\hline \multicolumn{1}{|c|}{ Construct } & $\mathbf{1}$ & $\mathbf{2}$ & $\mathbf{3}$ & $\mathbf{4}$ & $\mathbf{5}$ & $\mathbf{6}$ & $\mathbf{7}$ \\
\hline $\mathbf{1}$ Administer project close out & $\mathbf{0 . 9 0 2}$ & & & & & & \\
\hline 2 Develop project plan & 0.417 & $\mathbf{0 . 7 4 9}$ & & & & & \\
\hline 3 Manage design development and contract admin & 0.130 & 0.589 & $\mathbf{0 . 8 4 3}$ & & & & \\
\hline 4 Manage human resource function & 0.499 & 0.585 & 0.425 & $\mathbf{0 . 7 6 9}$ & & & \\
\hline 5 Manage project quality health safety and environment & 0.106 & 0.496 & 0.326 & 0.161 & - & & \\
\hline 6 Organize project initiations & 0.143 & 0.704 & 0.487 & 0.308 & 0.445 & $\mathbf{0 . 7 1 9}$ & \\
\hline 7 Tracking and controlling system & 0.662 & 0.488 & 0.416 & 0.525 & 0.222 & 0.209 & $\mathbf{0 . 7 3 6}$ \\
\hline
\end{tabular}

Note: Square root of the AVE on the diagonal

organizational skills (functional) represented a second major set of competencies for a good project manager; the characteristics included in this category were planning, analyzing, and goal setting. The results conform to the components included in the competency model for project managers in the Libyan construction industry developed by Omran et al. (2012). The model included project process skills that contain monitoring and controlling projects, developed projects, resources, and managed project execution. The results agree with the competencies included in the model developed by Dogbegah et

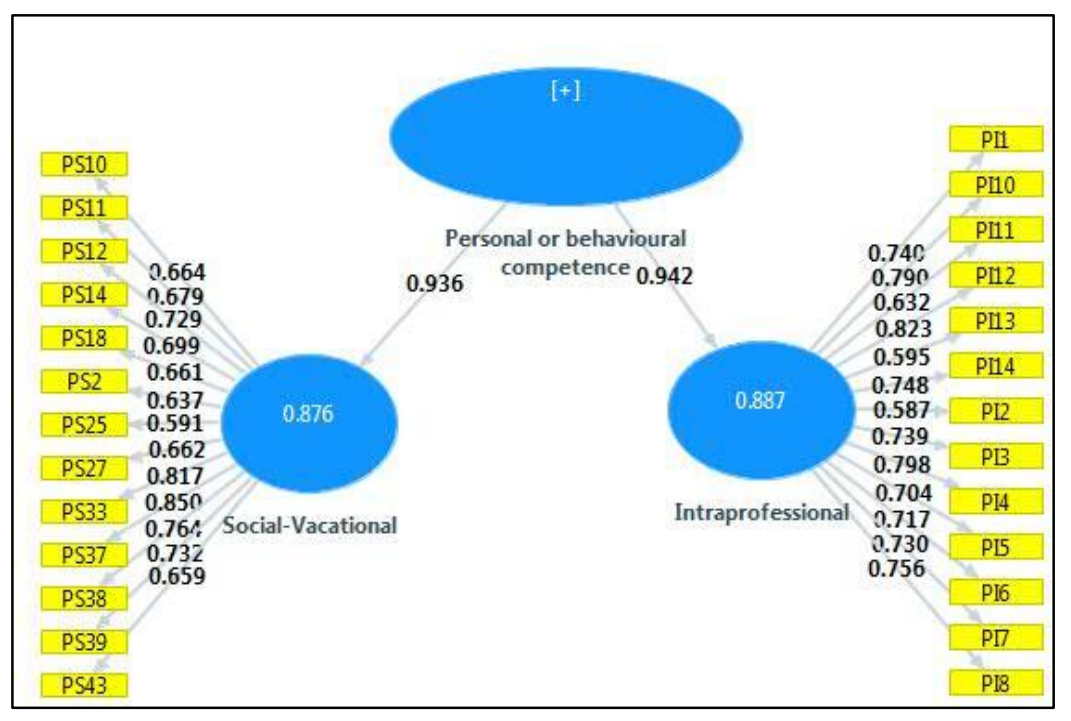

Figure 5. Personal Competence Factor Loadings al. (2011). The model included schedule management and planning as well as plant and equipment resources management. PMI (2013) divided project management competencies into three separate dimensions; the second one is performance competency. Each project management competency is demonstrated by different means. Performance competency is assessed during project-related actions and outcomes.

\section{Personal competence}

Personal or behavioral competence construct consists of two first-order constructs, socialvocational and intraprofessional construct. Figure (5) shows that the items were conducted gradually. PLS algorithm was run after each deletion to check the loading of items. Some items with low loading were deleted to increase the AVE value to above 0.5 . Figure (5) shows the valid items that satisfied the convergent validity of the firstorder personal competence constructs.

Table (8) presents the item loading, AVE, and composite 
Table 8. Results Summary of Item Loading, AVE and Composite Reliability of the Personal Competence Construct

\begin{tabular}{|c|c|c|c|c|}
\hline Construct & Item & $\begin{array}{c}\text { Main } \\
\text { loading }\end{array}$ & AVE & $\begin{array}{l}\text { Composite } \\
\text { Reliability }\end{array}$ \\
\hline \multirow[t]{13}{*}{ Intraprofessional } & Collegiality PI1 & 0.740 & 0.523 & 0.934 \\
\hline & Build trust PI10 & 0.790 & & \\
\hline & Read people PI11 & 0.632 & & \\
\hline & Resolve conflict PI12 & 0.823 & & \\
\hline & Sensitive to the needs of others PI13 & 0.595 & & \\
\hline & Concern to learn from experience PI14 & 0.748 & & \\
\hline & Positive expectations of others PI2 & 0.587 & & \\
\hline & Conformity to professional norms PI3 & 0.739 & & \\
\hline & Teamwork PI4 & 0.798 & & \\
\hline & Public relations PI5 & 0.704 & & \\
\hline & Interpersonal understanding PI6 & 0.717 & & \\
\hline & Team building PI7 & 0.730 & & \\
\hline & Relationship versatility PI8 & 0.756 & & \\
\hline \multirow{13}{*}{$\begin{array}{l}\text { Social- } \\
\text { Vocational }\end{array}$} & Reassurance PS10 & 0.664 & 0.500 & 0.928 \\
\hline & Stamina PS11 & 0.679 & & \\
\hline & Learn from mistakes PS12 & 0.729 & & \\
\hline & Analytical/ investigativePS14 & 0.699 & & \\
\hline & Perseverance PS18 & 0.661 & & \\
\hline & Self-control/stress resistant PS2 & & & \\
\hline & Facilitative PS25 & 0.591 & & \\
\hline & Proactive PS27 & 0.662 & & \\
\hline & Punctuality PS33 & 0.817 & & \\
\hline & Patience PS37 & 0.850 & & \\
\hline & Well-organized \& disciplined PS38 & 0.764 & & \\
\hline & Manage stress PS39 & 0.732 & & \\
\hline & Prepared to take responsibility PS43 & 0.659 & & \\
\hline \multirow{2}{*}{$\begin{array}{l}\text { Personal or } \\
\text { behavioral } \\
\text { competence } \\
\text { (Second order }\end{array}$} & Intraprofessional & 0.936 & 0.882 & 0.937 \\
\hline & Social-Vocational & 0.942 & & \\
\hline
\end{tabular}

Table 9. Correlations and discriminant validity of personal competence construct

\begin{tabular}{|l|l|l|}
\hline & Intraprofessional & Social-Vocational \\
\hline Intraprofessional & 0.723 & \\
\hline Social-Vocational & 0.762 & 0.707 \\
\hline
\end{tabular}

Note: Square root of the AVE on the diagonal

The Engineering Project Organization Journal (C)2017 Engineering Project Organization Society www.epossociety.org 
reliability of the personal competence construct. These values were satisfied. Thus, the convergent validity of personal competence construct was achieved.

Table (9) shows that the AVE values on the diagonal are greater than the correlation coefficient of the component with all other components in the personal competence construct, indicating that the discriminant validity was not fulfilled for all components. Therefore, cross-loading was assessed to ensure that the difference between main loading and cross loading is greater than 0.1 .

Table (8) shows cross-loading assessment that indicates three items (PI11, PS14, and PS18) have problematic issues in cross-loading assessment and should be deleted to satisfy the discriminant validation. The results agree with Cheetham and Chivers (1996), whose model included personal competence with two dimensions, namely, intraprofessional and social competencies. Boyatzis (2008) mentioned the three clusters of competencies that differentiate outstanding from average performers globally, the second and the third are emotional intelligence and social intelligence competencies, respectively. Dante and Ignacio (2012) stated that the components of professional competencies are a composite of personal attributes (capacities, motives, personality traits, self-image, aptitudes, attitudes, and values), which complement and integrate themselves in conjunction with other elements related to the context of work. Edum-Fotwe and McCaffer (2000) included social competencies in the primary knowledge and skill elements for developing project manager competency; according to the degree of importance, it comes in the second order and was named managerial skills. Zhang et al. (2013) identified the four dimensions of social competencies for construction project managers and focused on these attributes for construction project managers to develop their social competencies and perform better in the workplace, which improved the performance of the entire organization. Another study by Araujo and Taylor (2012) revealed that $70 \%$ of the variance of working performance is explained linearly by the total average of emotional and social competence. Othman and Jaafar (2013) identified the top three main personal competencies possessed by women project managers in Malaysia, namely, honesty and integrity, alertness and quickness, and decisionmaking ability. Male et al. (2011) studied the generic competencies required by engineers and found that it included technical and non-technical items and encompass attitudes. Non-technical and attitudinal competencies were rated as important as technical competencies. They also determined that several competencies that included attitudinal components received mean ratings of the importance of above four on the five-point scale. Omran et al. (2012) included the same competencies in their model for project managers in the Libyan construction industry and identified personal characteristics competence, which includes two constituents, namely, self-reflection and leadership/team management. Boyatzis (2008) stated that emotional competencies comprise personal and social competencies. Personal competencies should be included in any competency model, a view supported by Shamsudin and Chuttipattana (2012), who stated the three reasons why personality competencies may determine managerial competency. Leader personality influences the dynamics and culture of the top management team, and the characteristics of the top management team influence the performance of the organization. Transformational leaders tend to display a high level of confidence and self-esteem, which may inspire their subordinates to share a common vision and convince them of the possibility of reaching a goal higher than they expect. Personal characteristics, such as the ability of leaders to be persistent, careful, responsible, and hardworking, are important attributes for accomplishing work tasks in all jobs. The model of management competence by Boyatzis (1982) identified a number of behaviors, which are likely to be relevant to other professional areas and provide useful protocols for specifying behavioral competence. Cheetham and Chivers (1996) stated that personal competence may be a better predictor of capability (i.e., can perform in future posts) than functional competence, which attests primarily to competence within a candidate's current post. Tas et al. (1996) discovered that among the 18 competencies examined, interpersonal competency was rated the highest and followed by the leadership 
competencies; both were related to personal and behavioral competencies. Spencer and Spencer (1993) defined five characteristics of competency. Two can be assessed and developed through training. Three are considered core personality characteristics and are difficult to assess and develop: (a) motives, (b) traits, and (c) selfconcept.

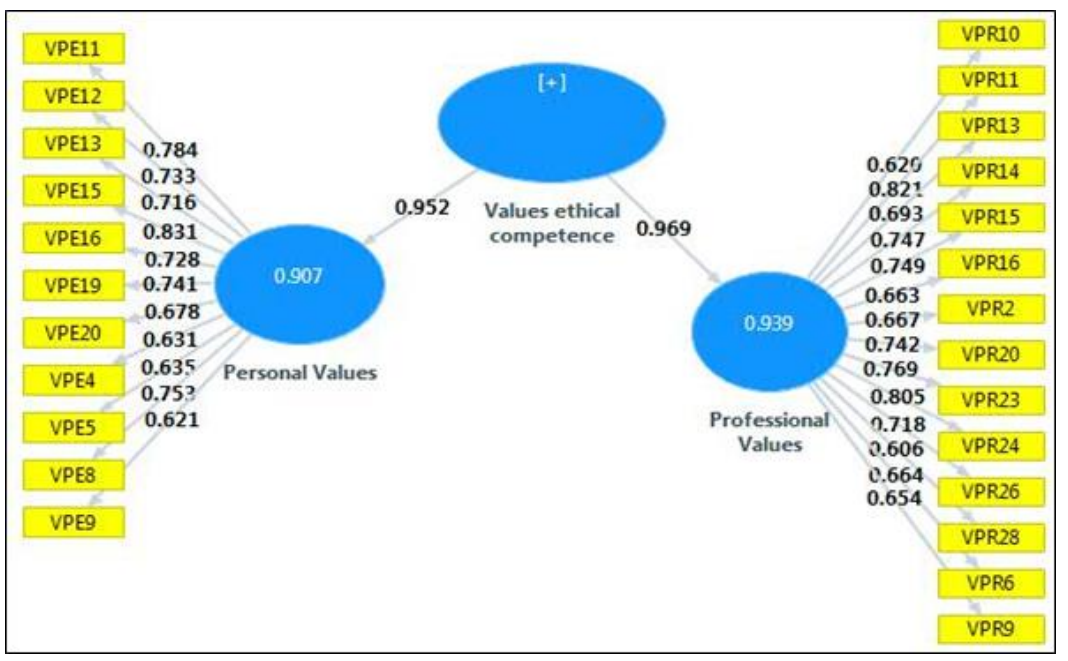

Figure 6. Values Competence Factor Loadings

\section{Values competence}

Values/ethical competence construct consists of two first-order constructs: personal values and professional values. Figure (6) shows that the deletion of the items was done one-by-one. PLS algorithm was run after each deletion to check the loading of the items. Some items with low loading were deleted to increase the AVE value to above 0.5 . Figure (6) shows the valid items that satisfied the convergent validity of the first-order constructs.

Table (10) shows the item loading, AVE, and composite reliability of the values competence construct. These values were satisfied; thus, the convergent validity of the values competence construct was achieved.

Table (11) shows that the AVE values on the diagonal are greater than the correlation coefficient of the component with all other components in the values competence construct. Thus, the discriminant validity was not fulfilled for all components. Therefore, cross-loading was assessed to ensure that the difference between main loading and cross loading is greater than 0.1 .

After deleting the items, discriminant results presented in Table (10) show acceptable values. The values competence items were validated by running the bootstrapping procedure. $T$ value was assessed for the standardized path coefficients by bootstrapping with 5000 resamples using smart PLS 3.0, as suggested by Hair et al. (2013). The results agree with Cheetham and Chivers's (1996) model, which included values competence with two dimensions, namely, personal and professional values competence. Skulmoski et al. (2000) concluded that soft competencies are important to the success of a project manager. "Even the most skilled project participant, with a deep understanding of the project management body of knowledge, might underperform if he lacks soft competencies, such as the achievement drive." Cheetham and Chivers (1996) believed that ethical judgments make a key contribution to professional performance and may have an explicit place within any model of professional competence. Values competencies are important to be included in any developed competency model; this statement is supported by Ozar (1993), who argued for ethics and values to become a standard part of professional development and had suggested ways in which this may be done; this statement is also supported by Walker et al., cited in Dogbegah et al. (2011), who stated that values/ethics should be considered in the model because people all have slightly different understandings of the concepts of ethics. Moral values are shaped over time, influenced by a range of factors, such as parents and upbringing, religion, formal and informal education, and cultural identity. Including values competence in construction project manager competence model is vital. Omran et al. (2012) included attitude competencies in their model for project managers in the Libyan construction industry and divided the 
Table 10. Results Summary of Item Loading, AVE and Composite Reliability of the Values Competence Construct

\begin{tabular}{|c|c|c|c|c|}
\hline Construct & Item & $\begin{array}{l}\text { Main } \\
\text { loading }\end{array}$ & $\overline{\text { AVE }}$ & $\begin{array}{l}\text { Composite } \\
\text { Reliability }\end{array}$ \\
\hline \multirow[t]{11}{*}{ Personal Values } & Open mindedness VPE11 & 0.784 & 0.513 & 0.920 \\
\hline & Specific VPE12 & 0.733 & & \\
\hline & Intuitive VPE13 & 0.716 & & \\
\hline & Creative VPE15 & 0.831 & & \\
\hline & motivation VPE16 & 0.728 & & \\
\hline & Motivation VPE19 & 0.741 & & \\
\hline & Relaxation VPE20 & 0.678 & & \\
\hline & Tenacity VPE4 & 0.631 & & \\
\hline & Independence VPE5 & 0.635 & & \\
\hline & Dynamic VPE8 & 0.753 & & \\
\hline & Concise and rational VPE9 & 0.621 & & \\
\hline \multirow{14}{*}{$\begin{array}{l}\text { Professional } \\
\text { Values }\end{array}$} & Broad base visualization VPR10 & 0.620 & 0.506 & 0.934 \\
\hline & $\begin{array}{l}\text { Receptive to alternative } \\
\text { solution/suggestions VPR11 }\end{array}$ & 0.821 & & \\
\hline & Prioritize VPR13 & 0.693 & & \\
\hline & Safety awarnessVPR14 & 0.747 & & \\
\hline & Quality awareness VPR15 & 0.749 & & \\
\hline & Health conscious VPR16 & 0.663 & & \\
\hline & Self-regulation VPR2 & 0.667 & & \\
\hline & Compromise VPR20 & 0.742 & & \\
\hline & Adaptable VPR23 & 0.770 & & \\
\hline & motivated VPR24 & 0.805 & & \\
\hline & Problem solving VPR26 & 0.718 & & \\
\hline & Transfer knowledge VPR28 & 0.606 & & \\
\hline & Client-cenerdness VPR6 & 0.664 & & \\
\hline & Thoroughness VPR9 & 0.654 & & \\
\hline \multirow{2}{*}{$\begin{array}{ll}\text { Values ethical } \\
\text { competence } \\
\text { (Second } \\
\text { construct) }\end{array}$} & Personal Values & 0.952 & 0.923 & 0.960 \\
\hline & Professional Values & 0.969 & & \\
\hline
\end{tabular}

Table 11. Correlations and discriminant validity of values competence construct

\begin{tabular}{|l|c|c|}
\hline & Personal Values & Professional Values \\
\hline Personal Values & 0.717 & \\
\hline Professional Values & 0.848 & 0.711 \\
\hline
\end{tabular}

Note: Square root of the AVE on the diagonal 
competencies to two constituents, which are personal and organization/project values. Eraut et al. (1994) identified four overlapping sets of values, which underpin ethical issues encountered at all levels in the workplace. These are legal (operating within the law and other mandatory systems), professional (relationships with clients and other professionals), organizational (relationships with colleagues, staff, customers, and the general public), and personal values (individual beliefs and behaviors). Ivanova (2012) developed a competency model by identifying the social competencies of successful engineering practice. She included several social competencies in the model, among the highest ranked abilities are loyalty and embracing change, both of which are related to values. Male et al. (2011) in their study on the generic competencies required by engineers included technical and non-technical items and encompass attitudes. They also found that several competencies that included attitudinal components received mean ratings of importance above 4 on the five-point scale (e.g., commitment, honesty, selfmotivation, demeanor, creativity, and concern for others). The model developed by Dogbegah et al. (2011) contained one competency component related to values, "ethical management." Ahadzie, Proverbs et al. (2008) highlighted project managers' soft skills (viewed as contextual performance behavior) as more critical predictors of project managers' performance than hard skills (viewed as task performance behaviors). Eraut et al. (1994) examined the need to build ethics into occupational standards and concluded that the incorporation of ethical issues within occupational standards is vital for the credibility of these standards. Goel (2006) conducted a comparative analysis of some engineering competencies distinguished and identified by several accreditation agencies of the US, the UK, Australia, Japan, and Singapore. The author recorded great similarities in the competency set identified by these accreditation agencies, and the core competencies include sensitivity toward ethical and professional issues.

\section{Ranking of Competence Components}

This section is attempted to rank the importance of the construction project managers' competencies according to their degree of importance. An ordinal measurement scale, which is a ranking of rating data that normally use integers in ascending or descending order, was used in this study. However, for analysing data by ordinal scale, a relative importance index (RII) was used. The RII is simple but effective technique and has been widely used in construction research for measuring attitudes with respect to surveyed variables (Alinaitwe et al., 2007; Chung et al., 2003; Naoum, 2007; Enshassi et al., 2012b). The respondents were asked to rank the competencies on a fivepoint Likert scale according to the degree of importance $(1=$ not very important; $2=$ unimportant; $3=$ neutral; $4=$ important; $5=$ very important). The RII was calculated based on the survey response as shown in Table (12) using the RII equation ((Lim \& Alum, 1995; Naoum, 2007; Enshassi et al., 2012b), as shown below:

$$
\begin{gathered}
\mathrm{RII}=5 \mathrm{n} 5+4 \mathrm{n} 4+3 \mathrm{n} 3+2 \mathrm{n} 2+1 \mathrm{n} 1 / \\
5 \mathrm{~N} * 100
\end{gathered}
$$

Where:

$n 1=$ number of respondents who answered "Not very important";

n2= number of respondents who answered "Unimportant";

$n_{3}=$ number of respondents who answered "Neutral";

$n_{4}=$ number of respondents who answered "Very important";

$n_{5}=$ number of respondents who answered "Very important".

The relative importance index (RII) for all the construction project managers' competencies was calculated. The group index was calculated by taking the average of factors in each group. The results in Table (12) depicts the 6 competencies under the knowledge competence have been placed in descending order where communication knowledge (RII=0.863) was found to be the most important dimension by the construction project managers in Palestine, followed by management knowledge (RII=0.849), this result is exactly the same result presented in Edum-Fotwe \& McCaffer (2000) study about competencies in the UK. 
Regarding technical and computer knowledge competencies, they are in the third place according to the study results, which is in contrast of EdumFotwe \& McCaffer (2000) results, who found technical and computer knowledge competence in the last place according to UK project managers. In the last place of ranking is the legal $(\mathrm{RII}=0.79)$ and general knowledge with (RII=0.78). It is apparent that project managers in Palestine not much concern about legal knowledge competencies as a result of depending on donors in controlling and dealing with any legal issues. Also, according to the results, it is clear that communication and computer knowledge are very important competencies according to the project managers in Palestine. These two competencies are important in Palestine as a result of needs to communicate with the donors who are foreigners from overseas (USA, Europe, and Japan). The donors require project managers to communicate with them orally and written. Also, they ask the project managers to submit all project documents in English language. For functional competence, the construction project managers in Palestine considered the top three important dimensions are administering project close-out ( $\mathrm{RII}=0.896)$, manage project tracking and controlling system (RII=0.869) and manage human resource function (RII=0.833), and the variable with the lowest degree of importance in this group is manage project quality, health, safety, and environment (RII=0.798). According to these results, it is obvious that the function of administrating project closeout and managing project tracking and controlling are very important more than the rest of the competencies in this group for the project managers in Palestine. That may mean project managers in Palestine are facing some problems in the stage of project close-out due to many reasons like time delay which is one the problems in the Palestinian construction industry as indicated in the literature review. So the need for tracking and controlling of the project appears from here. Regarding developing project plan and managing project quality, health, safety and environment, the project managers ranked them in the last place. This could be explained as a result of unavailability of workplace safety regulations and the absence of environmental protection procedures. For personal/behavior competence group, social/vocational competence $(\mathrm{RII}=0.87)$ is more important than intraprofessional competence $(\mathrm{RII}=0.825)$. For values/ethical competence, the construction project managers in the Palestinian construction industry considered personal values $(\mathrm{RII}=0.835)$ more important than professional values $(\mathrm{RII}=0.814)$. It is clear that the project managers in Palestine found personal and values are important competencies. Personal

Table 12. Ranking of Competence Components

\begin{tabular}{|c|c|c|}
\hline Competence & RII & Rank \\
\hline \multicolumn{3}{|c|}{ Knowledge Competence } \\
\hline Communication knowledge & 0.863 & 1 \\
\hline Management knowledge & 0.849 & 2 \\
\hline Computer knowledge & 0.844 & 3 \\
\hline Technical knowledge & 0.833 & 4 \\
\hline Financial knowledge & 0.812 & 5 \\
\hline Legal knowledge & 0.790 & 6 \\
\hline General knowledge & 0.780 & 7 \\
\hline Overall & 0.825 & 3 \\
\hline \multicolumn{3}{|c|}{ Functional Competence } \\
\hline Administer Project Close-out & 0.896 & 1 \\
\hline $\begin{array}{l}\text { Manage Project Tracking and Controlling } \\
\text { System }\end{array}$ & 0.869 & 2 \\
\hline Manage Human Resources Functions & 0.833 & 3 \\
\hline $\begin{array}{l}\text { Manage Design Development and } \\
\text { Contract Administration }\end{array}$ & 0.825 & 4 \\
\hline Organize Project Initiations & 0.824 & 5 \\
\hline Develop Project Plan & 0.821 & 6 \\
\hline $\begin{array}{l}\text { Manage project quality, health, safety and } \\
\text { environment }\end{array}$ & 0.798 & 7 \\
\hline Overall & 0.838 & 2 \\
\hline \multicolumn{3}{|c|}{ Personal / behavioral Competence } \\
\hline Social & 0.870 & 1 \\
\hline Intraprofessional & 0.825 & 2 \\
\hline Overall & 0.848 & 1 \\
\hline \multicolumn{3}{|c|}{ Values / ethical Competence } \\
\hline Personal value & 0.835 & 1 \\
\hline Professional value & 0.814 & 2 \\
\hline Overall & 0.824 & 4 \\
\hline
\end{tabular}


competencies considered the most important competence among other competencies. This indicates the needs for personal competencies in managing construction projects in the Palestinian industry. Finally, it is clear from Table (12) that personal competence was ranked by the Palestinian project managers at the top with $(\mathrm{RII}=0.848)$ followed by functional competence with $\mathrm{RII}=0.838$ followed by knowledge competence with ( $\mathrm{RII}=0.825)$, and in the last ranking is values competence with $(\mathrm{RII}=0.824)$. Through this part of analysis, Palestinian project managers can get information on which competencies are important and frequently used to manage construction projects. Recognizing project managers' competencies will help in creating and developing competent project managers, who are highly important to the success of construction projects.

\section{Conclusion}

This study attempted to identify the competence components of construction project managers in the Palestinian construction industry. This study identified four dimensions, namely, knowledge competence, functional competence, personal/behavior competence, and value/ethical competence. Each dimension is measured by several items called constituents. These constituents are also measured by several items named sub-constituents. Knowledge competence contains seven constituents measured by 34 items. Functional competence contains seven dimensions measured by 22 items. Personal/behavior competence contains two dimensions measured by 26 items. Value/ethical competence contains two dimensions measured by 14 items. The project manager in Palestine confirms the importance of acquiring the four dimensions of competence to be effective and competent project managers. Thus, one should have different competence dimensions, including technical and non-technical competencies, to be a competent project manager in the Palestinian construction industry. The degree of importance of the construction project managers' competencies was achieved by calculating the relative importance index of the competence dimensions and their items. The analysis results indicated that personal competence is in the top ranking and followed by functional competence, knowledge competence, and values competence. In the personal/behavior competence group, social/vocational competence was more important than intraprofessional competence. In functional competence, construction project managers considered administering project close out, handling a project tracking and controlling system, and managing human resource function as the most three important dimensions. Moreover, the variable with the lowest degree of importance in this group is managing project quality, health, safety, and the environment. In the knowledge competence group, communication knowledge was the most important dimension, followed by management knowledge, computer knowledge, and general knowledge. In the values/ethical competence, the construction project managers in the Palestinian construction industry considered personal values as more important than professional values. Therefore, despite the need of the project manager in Palestine to have the four dimensions of competence to be competent project managers, these competence dimensions have different degrees of importance. The present study proposed several recommendations to improve competencies. (i) Donors and owners of construction projects, such as the Palestinian government, should select and recruit construction project managers according to the competencies included in the model. (ii) Palestinian Contractors Union (PCU) in cooperation with the Palestinian Engineers Association (PEA) should improve the competencies of their members by conducting a continuous and up-to-date construction management training program and targeting the competencies included in the model. (iii) PCU and PEA drawing a comprehensive and precise criteria to review the classification given to contractors and consultants in construction firms could comprise the competencies of their construction project managers. This study contributes to knowledge in several ways. This study is the first of its kind in Palestine and one of the first studies done internationally to determine competencies of project managers in unstable countries under uncertain political situations, with limited resources, unstable economic situation, and exposure to restraints in the movement of goods and people, such as Palestine. Furthermore, it is 
important to know that the study did not correlate between project managers' competencies and the stability and limited resource economy of the country under study. However, for future studies and for the comparison purpose, it is recommended to do the same research on a country like Jordan which is adjacent to Palestine and has the same socio-economic situation with limited resources but with an exception it is a stable country with certain political situations, and has no restraints on the movement of goods and people. A study like that could help us to compare the results of both countries and find a connection between project managers' competencies and more variables like the political stability.

This study can be used as a guide to develop construction management training programs that target identified competencies in this study. Moreover, identified competencies could help evaluate construction project management education programs in Palestine. Furthermore, this work provides Palestinian project managers with information on which competencies are important and frequently used to manage construction projects. Construction managers can show how critical they are within a particular profession by measuring the importance of individual competencies.

\section{Acknowledgement}

The authors wish to express their sincere thanks to the participants in this study. Also, special thanks are extended to Assoc. Prof. Dr. Mohd Wira Mohd Shafiei for his valuable guidance and support in this research.

\section{References}

Ahadzie, D.K., Proverbs, D.G., \& Olomolaiye, P. (2008). Towards Developing Competency-Based Measures for Construction Project Managers: Should contextual behaviours be distinguished from task behaviours? International Journal of Project Management, 26(6), 631-645.

Alinaitwe, H.M., Mwakali, J.A., \& Hansson, B. (2007). Factors Affecting the Productivity of Building
Craftsmen Studies of Uganda. Journal of Civil Engineering and Management, 13(3), 169-176.

Allan, M., \& Chisholm, C.U. (2008). Achieving Engineering Competencies in the Global Information Society through the Integration of On-Campus and Workplace Environments. Industry and Higher Education, 22(3), 145-152.

Araujo, S.V.A., \& Taylor, S.N. (2012). The influence of Emotional and Social Competencies on the Performance of Peruvian Refinery Staff. CrossCultural Management: An International Journal, 19(1), 19-29.

Bedelian, H.M. (1996). Successful Major Projects in a Changing Industry. Proceedings of the Institution of Civil Engineers: Civil Engineering, 11(4), 117-123.

Bentil, K.K. (2012). Contemporary Construction Management Graduate Education: An industrydeveloped Masters Programme. The Organisation and Management of Construction: Shaping Theory and Practice, 3, 287-295.

Birnberg, H. (1992). New Directions in Architectural and Engineering Practice. London: McGraw-Hill.

Boyatzis, R.E. (1982). The Competent Manager: A Model for Effective Performance. New York: John Wiley.

Boyatzis, R.E. (2008). Competencies in the $21^{\text {st }}$ Century. Journal of Management Development, 27(1), 5-12.

Ceran, T., \& Dorman, A.A. (1995). The Complete Project Manager. Journal of Architectural Engineering, 1(2), 67-72.

Cheetham, G., \& Chivers, G. (1996). Towards a Holistic Model of Professional Competence. Journal of European Industrial Training, 20(5), 20-30.

Cheetham, G., \& Chivers, G. (1998). The Reflective and Competent Practitioner: A model of Professional Competence which Seeks to Harmonise the Reflective Practitioner and Competence-based Approaches. Journal of European Industrial Training, 267-276.

Cheetham, G., \& Chivers, G. (2005). Competence and Informal Learning. Cheltenham: Edward Elgar.

Chen, M.T. (1997). The Modem Project Manager. Cost Engineering, 39(3), 27-30.

Chen, P., Partington, D., \& Wang, J.N. (2008). Conceptual Determinants of Construction Project Management Competence: A Chinese perspective. International Journal of Project Management, 26(6), 655-664.

Chung, R.G., \& Wu, C.Y. (2011). The identification of Personnel Director's Competency Profile through the use of the Job Competence Assessment Method. African Journal of Business Management, 5(2), 405415. 
The Engineering Project Organization Journal (October 2017) 7, 2

CIDB (2002). Issues and Challenges in the Malaysian Construction Industry. Kuala Lumpur: CIDB.

Dante, G., \& Ignacio, D.R. (2012). Professional Competences: A classification of International Models. Procedia, 46, 1290-1296.

Dogbegah, R., Owusu-Manu, D., \& Omoteso, K. (2011). A Principal Component Analysis of Project Management Competencies for the Ghanaian Construction Industry. Australasian Journal of Construction Economics and Building, 11(1), 26.

Edum, F., Fotwe, T., \& McCaffer, R. (2000). Developing Project Management Competency: Perspectives from the Construction Industry. International Journal of Project Management, 18 (2), 111-124.

Enshassi, A., Al-Najjar, J., \& Kumaraswamy, M. (2009). Delays and Cost Overruns in the Construction Projects in the Gaza Strip. Journal of Financial Management of Property and Construction, 14(2), 126-151.

Enshassi, A., Mohamed, S., \& El Karriri, A. (2010). Factors Affecting the Bid/no Bid Decision in the Palestinian Construction Industry. Journal of Financial Management of Property and Construction, 15(2), 118-142.

Eraut, M., Steadman, S., Cole, G., \& Marquand, J. (1994). Ethics in Occupational Standards, NVQs and SVQs, Employment Department, Sheffield.

Fornell, C., \& Larcker, D.F. (1981). Evaluating Structural Equation Models with Unobservable Variables and Measurement Error. Journal of Marketing Research, 18, 39-50.

Fowler, B. (1994). MCI Personal Competence Model: Uses and Implementation, Employment Department, Sheffield.

Frank, T. (2002). The Superior Project Manager. New York: Marcel Dekker.

Gareis, R., \& Huemman, M. (1999). Specific Competencies in the Project-oriented Society, Project Management Days '99: Projects and Competencies, Vienna, 18-19 November.

Gilleard, J.D., \& Chong, W.S. (1996). New Challenges from Hong Kong's New Airport. In: Langford, D.A. and Retik, A., editors. The Organization and Management of Construction: Shaping Theory and Practice. 2. Spon, London, 767-777.

Goel, S. (2006). Competency focused Engineering Education with Reference to IT related Disciplines: Is the Indian System Ready for Transformation? Journal of Information Technology Education, 5(27), 27-52.

Gretton, I. (1993). Striving to succeed in a changing environment, Professional Manager, 15-17 July.
Hair, J.F., Black, W.C., Babin, B.J., \& Anderson, R.E (2010). Multivariate Data Analysis. New Jersey: Pearson Prentice Hall.

Hair, J.F., Hult, G.T.M., Ringle, C.M., \& Sarstedt, M. (2013). A Primer on Partial Least Squares Structural Equation Modeling (PLS-SEM). Thousand Oaks: Sage.

Hogg, B. (1993). European Managerial Competencies. European Business Review, 93(2), 21-26.

Hornby, D., \& Thomas, R. (1989). Towards a better Standard of Management, Personnel Management, Pan, London.

Hwang, B.G., \& Ng, W.J. (2012). Project Management Knowledge and Skills for Green Construction: Overcoming Challenges. International Journal of Project Management, 31, 272-284.

Ingason, H.T., \& Jónasson, H.I. (2009). Contemporary Knowledge and Skill Requirements in Project Management. Project Management Journal, 40(2), 59-69.

International Project Management Association (IPMA), (2006). International Competence Baseline, International Project Management Association. Retrieved 17, July 2012 from www.ipma.ch/certification.html.

Ivanova, M. (2012). Social Competencies Identification for Realization of Successful Engineering Practice. Interactive Technology and Smart Education, 9(4), 217-229.

Jannad, M.O. (1997). Reasons for Construction Business Failures in Saudi Arabia. Project Management Journal, 28(2), 32-36.

Jessup, G. (1991). Outcomes: NVQs and the Emerging Model of Education and Training, the Falmer Press, London.

Kangari, R. (1988). Business Failure in Construction Industry. Journal of Construction Engineering and Management, 1142, 172-190.

Kay, C., \& Moncarz, E. (2004). Knowledge, Skills, and Abilities for Lodging Management Success. Cornell Hotel and Restaurant Administration Quarterly, 45(3), 285-98.

Klemp, G.O. (1980). The assessment of Occupational Competence. Report to the National Institute of Education, Washington, DC.

Koenigsfeld, J.P., Youn, H., \& Perdue, J. (2012). Revised Competencies for Private Club Managers. International Journal of Contemporary Hospitality Management, 24(7), 1066-1087.

Lim, E.C., \& Alum, J. (1995) Construction Productivity: issues encountered by contractors in Singapore. International Journal of Project Management, 13(1), $51-58$.

Mahamid, I. (2011). Risk Matrix for Factors Affecting Time Delay in Road Construction Projects: Owners' 
The Engineering Project Organization Journal (October 2017) 7, 2

Perspective. Engineering, Construction and Architectural Management, 18 (6), 609-617.

Mahamid, I. (2012). Factors Affecting Contractor's Business Failure: Contractors' Perspective. Engineering Construction and Architectural Management, 19(3), 269-285.

Mahmood, A., Mahmood, A.M., \& Shafiei, M.W.M. (2006). What competencies do project managers need? In International Conference on Construction Industry (ICCI) (pp. 12-24).

Male, S.A., Bush, M.B., \& Chapman, E.S. (2011). An Australian Study of Generic Competencies Required by Engineers. European Journal of Engineering Education, 36(2), 151-163.

McClelland, D.C. (1998). Identifying Competencies with Behavioral Event Interviews. Psychological Science, 9 (5), 331-339.

Muller, C.C., \& Campbell, D.F. (1995). The Attributes and Attitudes of Multiunit Managers in a National Quick-Service Restaurant Firm. Hospitality Research Journal, 19(2), 3-18.

Muller, R., \& Turner, R. (2010). Leadership Competency Profiles of Successful Project Managers. International Journal of Project Management, 28, 437-448.

Naoum, S. (2007). Dissertation Research and Writing for Construction Students. $2^{\text {nd }}$ Edition. Elsevier Ltd.

Nicholas, J.M., \& Steyn, H. (2012). Project Management for Engineering, Business, and Technology. Fourth Edition. New York, USA: Routledge Taylor and Francis Group.

Omran, A., Bazeabez, A., Gebril, A.O., \& Wah, W.S. (2012). Developing Competency Model for the Project Manager in the Libyan Construction Industry. The International Journal of Economic Behavior, 2(1), 27-36.

Othman, N.L., \& Jaafar, M. (2013). Personal Competency of Selected Women Construction Project Managers in Malaysia. Journal of Engineering, Design, and Technology, 11(3), 276287.

Ozar, D.T. (1993). Building Awareness of Ethical Standards, in Curry, L. and Wergin, J.F. (Eds), Educating Professionals. San Francisco, CA: JosseyBass.

Palestinian Central Bureau of Statistics, (2010). Building Licenses Statistics; Third Quarter, 15 (3).

Palestinian Central Bureau of Statistics, (2012). Press Report. Preliminary Estimates of Quarterly National Accounts. First Quarter, Ramallah, Palestine.

Perdue, J., Ninemeier, J., \& Woods, R. (2000). Competencies Required for Club Managers. Cornell Hotel and Restaurant Administration Quarterly, 41 (2), 79-85
Pinto, J., \& Trailer, J. (1998). Leadership Skills for Project Managers. Newtown Square, PA: Project Management Institute, Inc.

PMI (2013). A Guide to the Project Management Body of Knowledge (PMBOK). Upper Darby, Pennsylvania: Project Management Institute Standards Committee, PMI.

Posner, B.Z. (1987). What it takes to be a Good Project Manager. Project Management Journal, 51-54.

Richmann, L. (2011). Successful Project Management. 3rd Edition. New York, USA: AMACOM, a division of the American Management Association International.

Ringle, C.M., Sarstedt, M., \& Straub, D.W. (2012). Editor's Comments: a critical look at the use of PLSSEM in MIS Quarterly. MIS Quarterly, 36(1), iii-xiv.

Ringle, C.M., Wende, S., \& Becker, J.M. (2014). Smart PLS 3.0. Hamburg: SmartPLS. Retrieved from http://www.smartpls.com

Russell, J.S., Jaselski, E.J., \& Lawrence, S.P. (1997). Continuous Assessment of Project Performance. Journal of Construction Engineering and Management, 1231, 64-71.

Ryan, G., Spencer, L.M., \& Bernhard, U. (2012). Development and Validation of a Customized Competency-based Questionnaire Linking Social, Emotional, and Cognitive Competencies to Business Unit Profitability. Cross-Cultural Management, 19 (1), 90-103.

Schroder, H.M. (1989). Managerial Competence: The Key to Excellence, Kendall/Hunt, Dubuque, IA.

Sears, S.K., Sears, G.A., \& Clough, R.H. (2008). Construction Project Management: A Practical Guide to Field Construction Management, $5^{\text {th }}$ edition. NJ, USA: Wiley, Hoboken.

Shamsudin, F.M., \& Chuttipattana, N. (2012). Determinants of Managerial Competencies of Primary Care Managers in Southern Thailand. Journal of Health Organization and Management, 26(2), 258-280.

Shenhar, A.J., Levy O., \& Dvir, D. (1997). Mapping the Dimensions of Project Success. Project Management Journal, 28(2), 5-15.

Skulmoski, G., Hartman, F., \& DeMaere, R. (2000). Superior and Threshold Project Competencies. Project Management, 6, 10-15.

Spencer, L.M. \& Spencer, S.M. (1993). Competence at Work: Models for Superior Performance. New York, NY: Wiley.

Tas, R.F., LaBrecque, S.V., \& Clayton, H.R. (1996). Property Management Competencies for Management Trainees. Cornell Hotel and Restaurant Administration Quarterly, 37(4), 90-96.

Tripathi, P., \& Sure, R.K. (2010). Development of Competence-based management and Performance 
The Engineering Project Organization Journal (October 2017) 7, 2

Assessment System for Academic Management: Empirical Investigation. International Journal of Innovation, Management, and Technology, 1(4), 357-361.

Turley, T., \& Bieman, M. (1994). Identifying Essential Competencies of Software Engineers, Proceedings of ACM Conference on Computer Science, pp. 271-8.

Vichita, V., \& Jintawee, T. (2007). Competency Requirements for Effective Job Performance in the Thai Public Sector. Contemporary Management Research, 3(1), 45-70.

Webster, R.M, \& Hillson, D. (2002). Scaling the PEAKS of Project Management Competency. PMI Europe, The Project Management Festival, $19-20^{\text {th }}$ June, Cannes, Hosted by PMI France-Sud.

Wetzels, M., Odekerken-Schroder, G., \& Van Oppen, C. (2009). Using PLS path modeling for assessing hierarchical construct models: guidelines and empirical illustration. Management Information Systems Quarterly, 33(1), 177-195.

Wickramasinghe, V., \& De Zoyza, N. (2009). An assessment of Managerial Competency needs: Empirical Evidence from a Sri Lankan Telecommunication Service Provider, The International Journal of Human Resource Management, 20(12), 2547-2567.

Worthington, R.L., \& Whittaker, T.A. (2006). Scale Development Research: A Content Analysis and Recommendations for Best Practices. The Counseling Psychologist, 34, 806-838.

Zhang, F., Zuo, J., \& Zillante, G. (2013). Identification and Evaluation of the Key Social Competencies for Chinese Construction Project Managers. International Journal of Project Management, 10, 748-759. 